\title{
Phage Therapy, The Best Choice To Overcome Antibiotic Resistance, But Can Never Replace Antibiotics
}

\section{G. Sunil paul}

Department of clinical pharmacy, Aditya Pharmacy College, East- Godavari District, Andhra-Pradesh, India

Corresponding author: G. Sunil paul, Department of clinical pharmacy, Aditya Pharmacy College, East- Godavari District, Andhra-Pradesh, India

Received date: February 27, 2020; Accepted date: April 20, 2020; Published date: May 06, 2020

Citation: G. Sunil paul, Phage Therapy, The Best Choice To Overcome Antibiotic Resistance, But Can Never Replace Antibiotics.. J Clinical Research and Reports, 4(2); DOI:10.31579/2690-1919/061

Copyright: (C) 2020 G. Sunil paul, This is an open access article distributed under the Creative Commons Attribution License, which permits unrestricted use, distribution, and reproduction in any medium, provided the original work is properly cited

\begin{abstract}
Phages are also known as bacteriophages which are normally viruses that infect and replicate within the bacteria. Phage therapy is the clinical use of these bacteriophages to treat infections caused by superbugs (bacteria that have acquired resistance against antibiotics). Phages when administered in to bacteria, causes the lysis of the bacterial cells in the lytic phase of phage life cycle. Phage therapy has acquired its importance in the recent years after their successful use in managing some life threatening infections and helped in saving lives. Phage therapy is currently being used as the antimicrobial therapy in some western countries. this paper mainly discusses about using phage therapy in treating infections caused by superbugs, and also discusses on what measures should be taken by different countries to successfully introduce the phage therapy in clinical use. Apart from this phage therapy has got some disadvantages which shows that phage therapy can never be an effective alternative for antibiotics. We conclude that phage therapy can be the best choice for treating infections caused by superbugs, where antibiotics can't work but can't be used again once used before in a particular patient.
\end{abstract}

Key Words: bacteriophages, replicate, superbugs, resistant, lytic phase, antimicrobial, therapy.

\section{Introduction}

[1] Phages are also known as bacteriophages which are normally viruses that infect and replicate within the bacteria. Phages were first discovered by Frederick W. Twort (1915) and also by Félix d'Hérelle (1917). In 1920 some scientists and physicians used phages in humans for treating various bacterial infections when antibiotics were not yet discovered. Later phages therapy was promoted by F.dHerelle who used to travel many countries and helped others on how to use phage therapy in humans. In 1940 phages have lost their importance due to the discovery of antibiotics. [18] G. ELIAVA institute of bacteriophages in Georgia has never lost its interest on phage therapy, they never quit their research on phages till now. The researchers used to collect phages from Environment sources and store them in phage bank. This collection of phages by the ELIAVA institute has provided information on which phages can be selectively used against bacteria isolated for personalized therapies. However data from a single institute is not sufficient to 1 . approve medicines all over the world. Due to wide spread in antibiotic resistance, it became very hard for the healthcare provider to treat bacterial infections, so the rest of the world along with G. ELIAVA institute has kept their interest in utilizing phage therapy for treating infections in humans caused by superbugs [18]. but there is a misconception that phage therapy can be a best alternative to antibiotic therapy. We cant completely replace antibiotics with phages, instead we can use them as adjavunt therapy. To approve phage therapy in clinical practice more data is needed which can be obtained by conducting more clinical trails. Studies which were conducted years ago do not provide enough data to approve phage therapy for clinical use. So, phage therapy will not be approved by the FDA until it clears all the stages of clinical trials. However, there are very few situations that phage therapy was very effective where antibiotics failed to do so. [4] These are abundant in nature and are present wherever the bacteria are found like soil, water, deep within the earth's crust. Oceans are a large source of phages it is estimated about $10^{30}$ bacteriophages in this world [4].

\section{Why phages can't replace antibiotics?}

[24] Phage are cleared rapidly from the bloodstream and provoke a response from the immune system. Using them for a systemic infection would be challenging, and you couldn't use them a second time on a patient. 
2. Phage are intrinsically narrow spectrum agents. Not only are they restricted to a single bacterial species, but usually to a subset of strains within that species. Dozens of phage strains are thus needed to cover the likely sources of any given infection. The same level of coverage can be attained with 1-2 antibiotics.

3. The phage efficacy data from Russia and elsewhere is very little. Most infections resolve even without treatment. Placebo-controlled antibiotic trials are rarely done now, due to ethical concerns. But trials from the 1930s and 1940s show $40-80 \%$ resolution of infections in the control arm.

4. ${ }^{[24]}$ Supportive care (these were mostly pneumonia patients) 1) is much better now, so that these numbers are lower bounds. A 2) convincing demonstration of efficacy requires very careful trial design, 3) and no one has come close to meeting a modern standard of proof with 4) phage therapy [24].

5. Antibiotics work most of the time. And they are cheap. This means that the market is small (phage would be used only as second- or third-line therapy) and pricing power would be low. There is not much hope of making money in phage therapy [24].

\section{Disadvantages of phage therapy.}

1. ${ }^{[25]}$ Narrow host range

2. Bacteria can also become resistant to phages.

3. Some phages can't conquer the bacterial immune system.

4. Infections whose agents are hidden in the human cells may be inaccessible to phages.

5. One type of phage can only me used once for intravenous use.

6. The self life of phages varies greatly.

7. Requires regular monitoring.

8. Phages are more difficult to administer than antibiotics which needs special training [24].
When and how these phages destroy the bacteria?

[19] Lytic phase is a part of phage life cycle, during which these phages produces specialized protein-based enzymes called lysins and send them into bacterial cytoplasm that are capable of degrading the bacterial cell wall and finally causes the lysis of bacteria.

[19] How phages destroy the bacteria: phages after invading the bacteria undergo following steps.

\section{Attachment}

Entry of phage DNA and degradation of host DNA

Synthesis of viral (phage) genomes and proteins

Assembly

Release

$[19,4]$ With their tail fibers these phages get attached to the bacterial cell wall. After the process of attachment these phages release their DNA into the host cell or bacterial cell, which causes the degradation of bacterial DNA after being incorporated into it. Then these phages their own viral genomes and proteins, all these genomes and proteins are assembled together to form a new phage. All these steps takes place during the lysogenic phase of phage life cycle [19,4].

After producing enough phages, these phages produces some proteins called lysins which causes the lysis of bacterial cell wall and are released out of the bacterial cell to attack other cell. This happens in the lytic phase of phage life cycle [19].

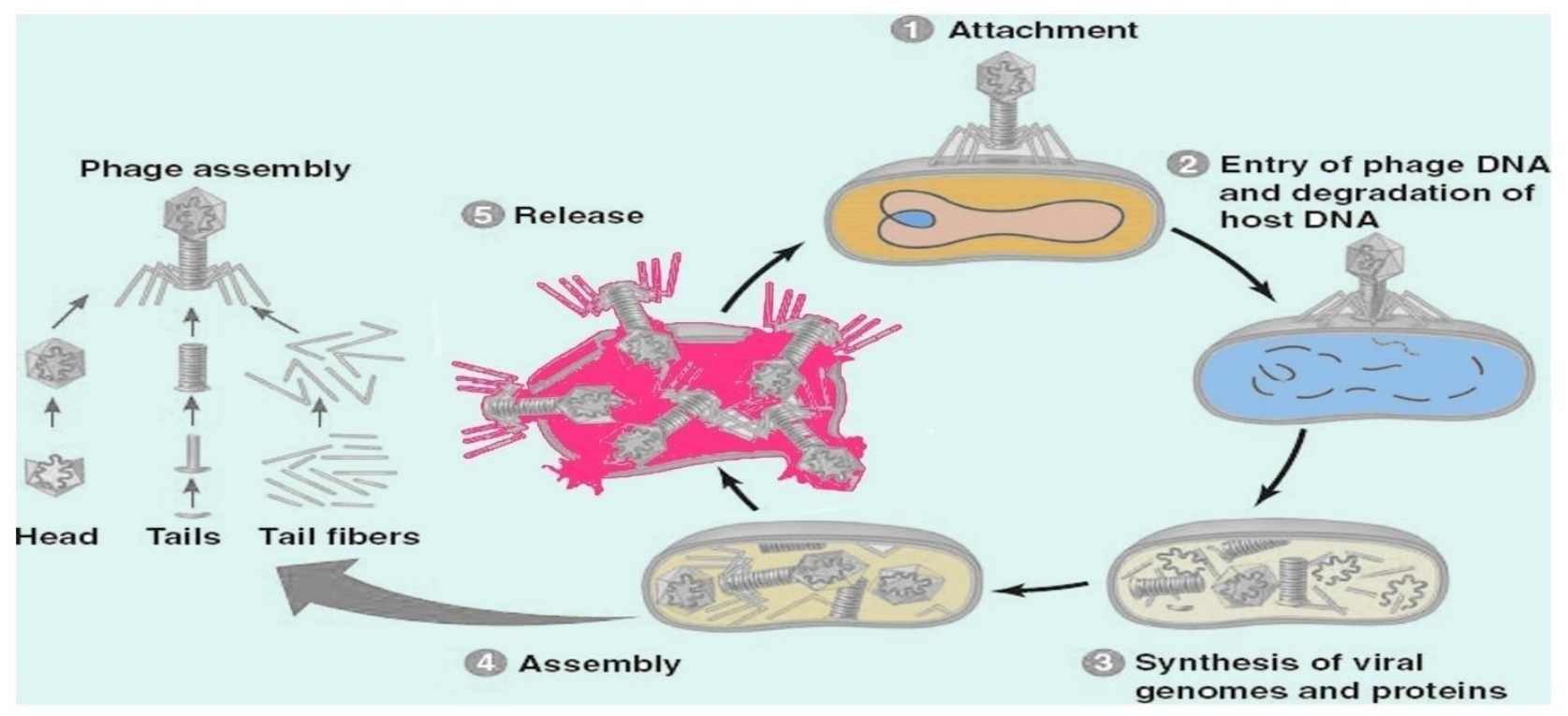


Reasons for antibiotic resistance?

[11] Bacteria are becoming resistant due to improper use of antibiotics. These bacteria have been developing different defence machanisms to protect them from antibiotics.

- [20] Restrict access to the antibiotics: By limiting the number or reducing the size of pores in cell-walls, bacteria are inhibiting the entry of sufficient amount of antibiotic into their cytoplasm.

- Get rid of antibiotics: Some bacteria can uses active pumps present in their cell walls to flush out antibiotic that is being entered into it.

- Degradation of the antibiotic: Some bacteria uses enzymes to break down the antibiotic drug and make them inactive. Eg:beta-lactamase.

\begin{tabular}{|r|c|c|}
\hline S.no & Lytic enzyme & Target pathogens \\
\hline I. & ABgp46 & $\begin{array}{c}\text { MDR Acinetobacter baumannii, Pseudomonas } \\
\text { aeruginosa, and Salmonella }\end{array}$ \\
\hline II. & PlyF307 & MDR A. baumannii \\
\hline III. & Cpl-1 & Mtreptococcus pneumoniae \\
\hline IV. & Cocktail of 6 distinct lysins & Clostridium difficile \\
\hline V. & PlyCD & Streptococcus pyogenes and MRSA \\
\hline VI. & PlySs2 & Bacillus anthracis \\
\hline VII. & PlyG & PRS \\
\hline
\end{tabular}

These are few phage enzymes that infect and lyse the host cell [1].

Measures to be taken to prevent antibiotic resistance:

1. [14] Judicious antibiotic use.

2. Use of specific antibiotics.

3. Surveillance and infection control [14]

4. Only use antibiotics for bacterial infections. Antibiotics will not treat viral infections like colds, flus, and bronchitis.

5. Don't use antibiotics if you don't need them.

6. Don't pressure your doctor to prescribe antibiotics for you or your child.

7. Take all antibiotics exactly as prescribed.

8. Complete the full dosage of antibiotics, even if you feel better.

9. Don't take expired antibiotics.

10. Throw away expired or unused antibiotics.

[14] These measures are helpful in controlling the further resistance but can't treat infections caused by bacteria which are already resistant to antibiotics. So the world is focussing on different methods to treat infections caused by superbugs [11].

So the only weapon that we have now to overcome antibiotic resistance is phage therapy but this can not be used more than once in a patient.
- Alter the antibiotic: Some bacteria uses enzymes to alter the antibiotics and make them inactive.

- Bypass the effect of antibiotic: some bacteria changes the composition or the structure of target in them, this can stop the antibiotics from binding with the target and makes the antibiotic ineffective [20].

$[11,14]$ Due to these reasons there is a need to find an alternative way to get rid of these resistant bacteria (superbugs) [11,14].

Examples of some lytic enzymes produced by phages and their specific hosts [1]:

When and how to use phage therapy in humans?

[19] The phage therapy involves the use of bacteriophages, which are perfect weapons to kill the bacteria. These superbugs are dangerous to human body cells which make the person ready to die.

1. We should start the antibiotics as usual.

2. Follow up the patient for improvement of symptoms.

3. If the symptoms are still worsening, then go for microbial sensitivity test.

4. If the microbe is sensitive to a particular antibiotic but the symptoms are still there, increase the dose of antibiotic.

5. If still the symptoms are there or the microbe is not sensitive to any antibiotic then go for phage therapy with caution

Note : always choose antibiotic therapy as $1^{\text {st }}$ line therapy

If any other alternative is available, consider it as $2^{\text {nd }}$ line therapy

If there is no option and the patient is about to die then consider phage therapy as $2^{\text {nd }}$ or $3^{\text {rd }}$ line therapy

\section{Discussion:}


In almost all cases where phage therapy was used, the scientists tried these phages only when the patient is about to die, this shows us that how danger the phage therapy is to humans. Apart from that we only have case reports which were successful. Phages are very dangerous when compared to antibiotics, [25] One of the best described disease-specific alterations in the gut phagobiome is associated with inflammatory bowel disease, where phages have pathogenic effects by inducing dysbiosis and microbiota disease [25]. So we should not use phages for treating infections which can be treated by antibiotis. We can use phages therapy as a last line therapy when there is no choice. Apart from that we can help to prevent antibiotic resistance by increasing awareness among the people.

\section{Conclusion:}

So we conclude that phage therapy can only be a last choice for treating infections and can also be used as a supportive therapy but will never replace antibiotics.

\section{References:}

1. Phage therapy: An alternative to antibiotics in the age of multidrug resistance Derek M Lin, Britt Koskella, Henry C Lin World J Gastrointest Pharmacol Ther 2017 August 6; 8(3): 162-173 ISSN 2150-5349 (online)

2. Wright, A., Hawkins, C. H., Anggard, E. E., and Harper, D. R. (2009). A controlled clinical trial of a therapeutic bacteriophage preparation in chronic otitis due to antibioticresistant Pseudomonas aeruginosa; a preliminary report of efficacy.Clin.Otolaryngol. 34, 349-357. doi: 10.1111/j.17494486.2009.01973.x

3. Chanishvili N. Phage therapy--history from Twort and d'Herelle through Soviet experience to current approaches. Adv Virus Res 2012; 83: 3-40 [PMID: 22748807 DOI: 10.1016/B978-0-12-394438 2.0000 1-3]

4. Suttle CA. Marine viruses--major players in the global ecosystem. Nat Rev Microbiol 2007; 5: 801-812 [PMID: 17853907 DOI: $10.1038 /$ nrmicro1750]

5. Wittebole X, De Roock S, Opal SM. A historical overview of bacteriophage therapy as an alternative to antibiotics for the treatment of bacterial pathogens. Virulence 2014; 5: 226-235 [PMID: 23973944 DOI: 10.4161/viru.25991

6. Ackermann HW. The first phage electron micrographs. Bacteriophage 2011; 1: 225-227 [PMID: 23050215 DOI: 10.4161/bact.1.4.17280] 5 Yoshikawa TT. Antimicrobial resistance and aging: beginning of the end of the antibiotic era? J Am Geriatr Soc 2002; 50: S226-S229 [PMID: 12121517]

7. Laxminarayan R, Duse A, Wattal C, Zaidi AK, Wertheim HF, Sumpradit N, Vlieghe E, Hara GL, Gould IM, Goossens H, Greko C, So AD, Bigdeli M, Tomson G, Woodhouse W, Ombaka E, Peralta AQ, Qamar FN, Mir F, Kariuki S, Bhutta ZA, Coates A, Bergstrom R, Wright GD, Brown ED, Cars O. Antibiotic resistance-the need for global solutions. Lancet
Infect Dis 2013; 13: 1057-1098 [PMID: 24252483 DOI: 10.1016/S1473-3099(13)70318-9]

8. Zhang XX, Zhang T, Fang HH. Antibiotic resistance genes in water environment. Appl Microbiol Biotechnol 2009; 82: 397414 [PMID: 19130050 DOI: 10.1007/s00253-008-1829-z]

9. Centers for Disease Control. Antibiotic Resistance: The Global Threat. 2015; Accessed Mar 29, 2017. Available from: URL: https:// www.cdc.gov/drugresistance/pdf/antibiotic_resistant_fs.pdf

10. World Health Organization. Antibiotic resistance - a threat to global health security. 2013. Accessed Mar 29, 2017. Available from: URL: http://www.who.int/drugresistance/activities/wha66_side_eve $\mathrm{nt} / \mathrm{en} /$

11. Boucher HW, Talbot GH, Bradley JS, Edwards JE, Gilbert D, Rice LB, Scheld M, Spellberg B, Bartlett J. Bad bugs, no drugs: no ESKAPE! An update from the Infectious Diseases Society of America. Clin Infect Dis 2009; 48: 1-12 [PMID: 19035777 DOI: $10.1086 / 595011]$

12. Luepke KH, Suda KJ, Boucher H, Russo RL, Bonney MW, Hunt TD, Mohr JF. Past, Present, and Future of Antibacterial Economics: Increasing Bacterial Resistance, Limited Antibiotic Pipeline, and Societal Implications. Pharmacotherapy 2017; 37: 71-84 [PMID: 27859453 DOI: 10.1002/phar.1868]

13. Centers for Disease Control and Prevention. Vital signs: carbapenem-resistant Enterobacteriaceae. MMWR Morb Mortal Wkly Rep 2013; 62: 165-170 [PMID: 23466435]

14. United Nations. PRESS RELEASE: High-Level Meeting on Antimicrobial Resistance. 2016; Accessed Mar 29, 2017.

Available from: URL: http://www.un.org/pga/71/2016/09/21/press-releasehlmeeting- on-antimicrobial-resistance/

15. Bourdin G, Navarro A, Sarker SA, Pittet AC, Qadri F, Sultana S, Cravioto A, Talukder KA, Reuteler G, Brüssow $\mathrm{H}$. Coverage of diarrhoea-associated Escherichia coli isolates from different origins with two types of phage cocktails. Microb Biotechnol 2014; 7: 165-176 [PMID: 24528873 DOI: 10.1111/1751-7915.12113]

16. Donlan RM. Preventing biofilms of clinically relevant organisms using bacteriophage. Trends Microbiol 2009; 17: 66-72 [PMID: 19162482 DOI: 10.1016/j.tim.2008.11.002]

17. Wahida A, Ritter K, Horz HP. The Janus-Face of Bacteriophages across Human Body Habitats. PLoS Pathog 2016; 12: e1005634 [PMID: 27337144 DOI: 10.1371/journal.ppat.1005634]

18. Phage Therapy in the Postantibiotic Era Fernando L. Gordillo Altamirano, Jeremy J. Barr DOI: 10.1128/CMR.00066-18

19. Bacteriophage Structure and Mechanism of Action, and their Application in Medical and Industrial Biotechnologies Online Event (17th-19th of January, 2017) - Research and Markets 
20. Mechanisms of bacterial resistance to antibiotics. Dever $\mathrm{LA}^{1}$, Dermody TS. 1991 May;151(5):886-95.

21. Phage Therapy for a Multidrug-Resistant Acinetobacter baumannii Craniectomy Site Infection Stephanie LaVergne, Theron Hamilton, Biswajit Biswas, M Kumaraswamy, R T Schooley, Darcy Wooten Open Forum Infectious Diseases, Volume 5, Issue 4, April 2018, ofy06

22. Reviving Phage Therapy for the Treatment of Cholera. Bhandare S, Colom J, Baig A, Ritchie JM, Bukhari H, Shah MA, Sarkar BL, Su J, Wren B, Barrow P, Atterbury RJ
23. Characterization Of Bacteriophages With Broad Host Range Against Strains Of Pseudomonas Aeruginosa Isolated From Domestic Animals (2019)19:134

24. Answer by Drew Smith, Former CSO at MicroPhage, on Quora: Mar 28, 2018, 01:21pm

25. Bacteriophages as New Human Viral Pathogens George Tetz and Victor Tetz
This work is licensed under Creative Commons Attribution 4.0 License

\section{To Submit Your Article Click Here: Submit Article}

DOI:10.31579/2690-1919/061
Ready to submit your research? Choose Auctores and benefit from:

* fast, convenient online submission

* rigorous peer review by experienced research in your field

* rapid publication on acceptance

* authors retain copyrights

* unique DOI for all articles

* immediate, unrestricted online access At

Auctores, research is always in progress.

Learn more https://www.auctoresonline.org/journals/journal-ofclinical- research-and-reports 